\title{
ASSIMILATION PROCESS OF PREFIXES IN THE SASAK LANGUAGE (STUDY OF GENERATIVE PHONOLOGY)
}

\author{
Rizky Mega Susanti \\ Magister of Linguistics \\ Diponegoro University \\ Semarang, Indonesia \\ mega92rizky@gmail.com
}

\begin{abstract}
This research discussed the rules of regional language in Indonesia, namely Sasak language. It described the phonological study that emerged from the daily speech of Lombok people, using Sasak language. The phonological study here discussed the assimilation process of prefiks that occurs in the Sasak language. The research method used was agih method followed by the technique for the direct element, which is to divide the lingual units and form the lingual unit in question. The analysis was done by using a generative phonological study approach, to find the sound change process that occurs in Sasak language. The data was obtained from Sasak morphophonemic research journal. This study used secondary data that has been tested for its reliability through research conducted previously. The result of research showed that in Sasak language there is assimilation process. Furthermore, it can be concluded that phonological process in Sasak prefiks has the same rule and meaning that is as the actor (noun). The assimilation process occurs from nasal sounds that meet with consonants and vowels, and cause sound changes in the phonemes.
\end{abstract}

Key words-- Sasak Language, Prefiks, Phonological Process, Assimilation Process, Generative Phonology

\section{INTRODUCTION}

\section{A. BACKGROUND of THE STUDY}

Language riches that exist in Indonesia represents the characteristic of each region. The Sasak language is one of regional languages owned by Indonesia. This language spreads through Lombok Island, Nusa Tenggara Barat province. Moreover, its language family is the same as the Sumbawa language, because it is influenced by the adjacent geographical location, but this language has a system of speech levels which are similar to Balinese and Javanese. Furthermore, it has prefix formation which is included into a part of affix. The affixation process is closely related to phonological process, it can be seen from some prefixes in which assimilation and different word formation caused by phonological process in the middle of morphological process have occurred.

The phenomenon of Sasak characteristic is seen from the prefix [peN] which is inherent in verb and changing verb into noun. For example, the word bisok which has Indonesian meaning cuci (wash) is added by the prefix [peN] so that it becomes pəmbisok and changes into noun or referring to person who is doing the action. Consequently, it is the reason why the different prefix and meaning reference is interesting to be investigated including about the process of prefix assimilation, its formula, and its analysis by implementing the theory of generative phonology, particularly distinctive feature.

This study is aimed to explain the process of assimilation occurred in the prefix of Sasak, to know how this problem is solved based on the phonological formulas, and to know the result of analysis through the implementation of generative phonology theory; distinctive feature.

\section{B. Theoretical Review}

A previous study that is considered as reference in completing this study is entitled "Bahasa Pergaulan Remaja: Analisis Fonology Generatif" (Language of Adolescent's Intercourse: Analysis of Generative Phonology) that had been conducted by Ni Wayan Sartini (2012), this study focused on word types of adolescent's intercourse language which tends to be concise and short. The theory used by the researcher was the analysis of generative phonology in order to answer some cases found in the study; they were the words of adolescent's intercourse in which the change of diphthong, the change of vowel, abbreviation or contraction, having formula of noun, the change of infix, the use of verb in, and the deletion of some particular sounds have occurred. In this study, it was also found some phonological features in the language of adolescent's intercourse, such as preference of using the vowel $/ \mathrm{e} /, / \mathrm{o} /$, and $/ \mathrm{\partial} /$, deletion of sound, weakening, strengthening, and blending of the vowel.

Muhsiyana Nurul Aisyiyah's (2017) study entitled "Proses Fonologis Pada Prefiks / $\mathrm{mo}-/$ Dalam Bahasa Gorontalo" (Phonological Process of Prefix /mo-/ in Gorontalo Language) also becomes the reference of completing this study. The result indicated that in the process of using prefix /mo-/ toward the basic morpheme of Gorontalo language, it was found the phonological processes, they were the addition of consonant $[\mathrm{n}]$ and the assimilation of consonantvowel. The addition of [y] occurred when the prefix /mo-/ was added into the basic morpheme that was preceded by the vowel sound. Furthermore, prefix / $/ \mathrm{mo}-/$ was active prefix or frequently used in daily conversation of Gorontalo language and meant doing something.

Another previous study that was entitled "Morfofonemik Dalam Proses Afiksasi Bahasa Sasak Desa Montong Baan Kecamatan Sikur Lombok Timur" (Morphophonemic of the Affixation Process in Sasak Language in Montong Baan, Sikur, East Lombok) was completed by Baiq Indah Yusdarani in 2015. Actually, this study did not discuss the phonological process, but it focused on the affixation process by implementing morphophonemic theory. The researcher emphasized in the process of change, addition and omission toward the phoneme toward morphophonemic of Sasak in Montong Baan.

Furthermore, based on the research problems mentioned before, the researcher tries to get the data in order to be further investigated 
by implementing the process of prefix assimilation and the theory of generative phonology. Therefore, this study will present the different data and discussion from the previous studies.

\section{RESEARCH METHODS}

Method is the way that must be done, while technique is the way of completing the method (Sudaryanto, 1993: 9). The stages which are going to be conducted in this study are data collection, data analysis, and result analysis presentation. In this study, the data that will be analysed are the secondary data obtained from the existing source; the data source from research journal.

The method that is implemented in this study is distributional method which is then continued by the implementation of its basic technique which is called as segmenting immediate constituents technique. Distributional method, based on Sudaryanto's book, is defined as a method in which its determiner tool is a part of the language itself. According to Sudaryanto (1993: 31), segmenting immediate constituents technique is the basic distributional method, it is called as segmenting immediate constituents technique because the way that is used in the beginning of analysis is segmenting the related lingual unit of the data which is then considered as immediate part to form the lingual unit mentioned before. The next step after data collection is data grouping based on the sound change that occurs, then the change is analysed by using the theory of generative phonology. Furthermore, the presentation of result of analysis will be presented in discussion section of this study.

\section{FINDINGS AND DISCUSSION}

The prefix $[\mathrm{peN}]$ is the former prefix of verb; the prefix that is inherent in the stem verb and changes the word class into noun, which means the notion of doing the work mentioned by the stem. According to Chaer (1994: 132), the assimilation process is the change of particular sound into another sound as the result of the sounds that exist in its environment, so this sound becomes the same or has the similar characteristic to the sound that influences it. The following data show the distribution of the sound variation from the prefix [peN] in Sasak:

\begin{tabular}{|c|c|c|c|}
\hline No. & Stem & Active Verb & $\begin{array}{c}\text { Indonesia } \\
\text { Meaning }\end{array}$ \\
\hline 1. & [bisok] & [pəmbisok] & Pencuci \\
\hline 2. & [bolek] & [pəmbəlek] & Pembesar \\
\hline 3. & [biran] & [pәmbiran] & Penghitam \\
\hline 4. & [boit] & [pəmbəit] & Pengambil \\
\hline 5. & [boliq] & [pambaliq] & Pembalik \\
\hline 6. & [putek] & [pəmutek] & Pemutih \\
\hline 7. & [pətวџ] & 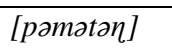 & Penggelap \\
\hline 8. & [pilek] & [pamilek] & Pemilih \\
\hline 9. & [petak] & [pəmetak] & Pencari \\
\hline 10. & [pənOk] & [pәтәnOk] & Pembanyak \\
\hline 11. & [tateh] & [panateh] & Pembuang \\
\hline 12. & [tarik] & [panarik] & Penjatuh \\
\hline 13. & [tukah] & [pәnukah] & Penukar \\
\hline
\end{tabular}

\begin{tabular}{|c|c|c|c|}
\hline 14. & [tulun] & [ponuluп] & Penolong \\
\hline 15. & [sion] & [penion] & Penggoreng \\
\hline 16. & [səpuh] & [рәләриһ] & Penyapu \\
\hline 17. & [saran] & [pәдәran] & Penyisir \\
\hline 18. & [sadut] & [panadut] & Pembakar \\
\hline 19. & [sarik] & [pənətik] & Penghapus \\
\hline 20. & [ontuk] & 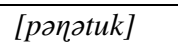 & Penarik \\
\hline 21. & [irak] & [paniraq] & Pengajak \\
\hline 22. & [ajak] & [panajak] & Pembohong \\
\hline 23. & [ukiq] & [panukiq] & Pengorek \\
\hline 24. & [OlOk] & [panOlOk] & Penyindir \\
\hline 25. & [kalak] & 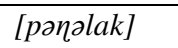 & Pemasak \\
\hline 26. & [kraiq] & 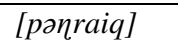 & Penggaruk \\
\hline 27. & [kalik] & 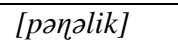 & Penggali \\
\hline 28. & [kodək] & 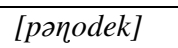 & Pengecil \\
\hline 29. & [garo] & [pongaro] & Pengering \\
\hline 30. & {$[g \partial c O q]$} & 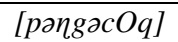 & Pemotong \\
\hline
\end{tabular}

Based on the data above, the environment can be determined by each sound variation. The following environment shows that the sound [peN-] has a broad distribution:
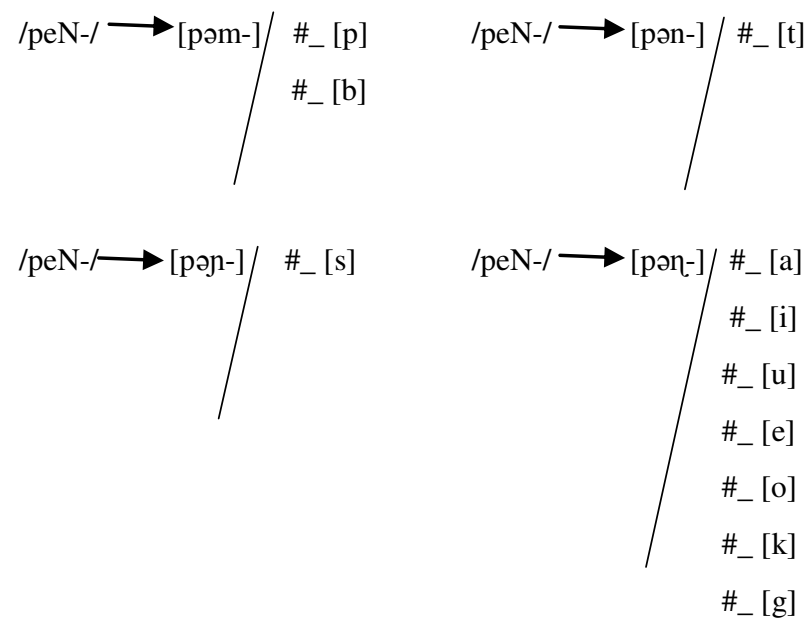

From the classification above, it can be arranged a particular formula for the assimilation process that occurs in Sasak based on the complete distinguishing feature. Since there is consonant sound variation in which the change of phonological process has occurred, the explanation of analysis process is based on the occurrence of assimilation process. Schane (1992:53) said that nasal consonant usually becomes homophone with the next consonant, or nasal consonant can take the same articulation area. The formula will be described as follows:

\section{a. Formula I}

The occurrence of assimilation process is from the phoneme /N/ which is transformed into [m] when it comes together with the sound 
[b,p], so the assimilation process can be explained by the following data:

Data 1

\begin{tabular}{|c|c|c|}
\hline + bisokl & [pəmbisok] & ci” \\
\hline /peN- + bolek/ & [pambalek] & "pembesar" \\
\hline 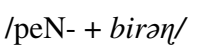 & [pәmbiran] & "penghitam" \\
\hline$/ \mathrm{peN}-+b z$ & [pəmbəit] & "pengambil" \\
\hline peN- + baliq & [pəmbaliq] & "pembalik" \\
\hline
\end{tabular}

The data 1 show that the uvular nasal consonant /N/ will turn into bilabial nasal $[\mathrm{m}]$ when it appears before [b] so that the distinguishing characteristic and its formula can be explained as follows:

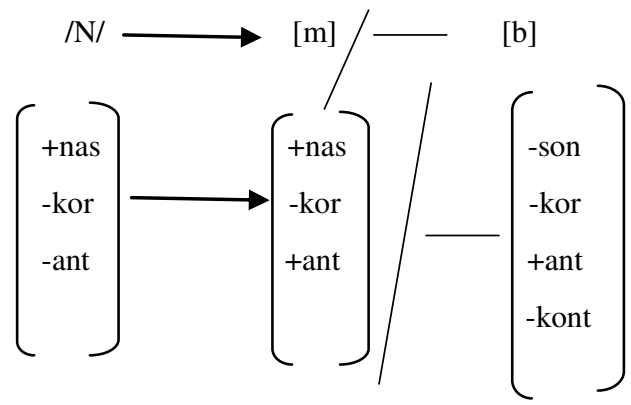

Data 2

$$
\begin{aligned}
& \text { /peN- + putek/ } \longrightarrow \text { [pəmutek] "pemutih" }
\end{aligned}
$$

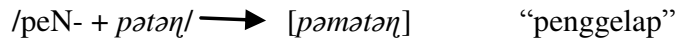

$$
\begin{aligned}
& \text { /peN- + pilek } / \longrightarrow \text { [pəmilek }] \quad \text { "pemilih" } \\
& \text { /peN- + petakl } \longrightarrow[\text { pəmetak }] \quad \text { "pencari" } \\
& / \mathrm{peN}-+ \text { pənOk } / \longrightarrow[\text { pəmənOk }] \text { "pembanyak" }
\end{aligned}
$$

Data 2 indicate that uvular nasal consonant $/ \mathrm{N} /$ will turn into bilabial nasal $[\mathrm{m}]$ when it comes before $[\mathrm{p}]$, and there is deletion process of the beginning phoneme in the basic feature. The assimilation process occurs with the sound that follows. So, the distinguishing characteristic and its formula are described below:

The first assimilation process

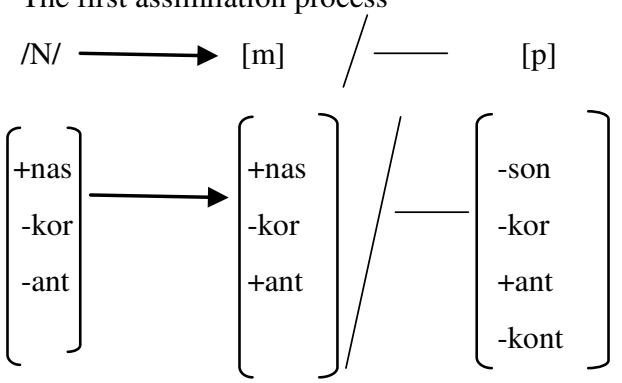

The second assimilation process which appears in the case above is deletion, this formula is considered as consequence of assimilation process. The process of phonological deletion is the process of deleting one of sounds toward the word in which the affixation occurs. The process will be described as follows:

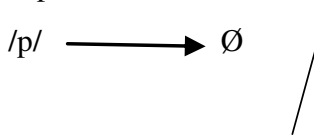

$[\mathrm{m}]$

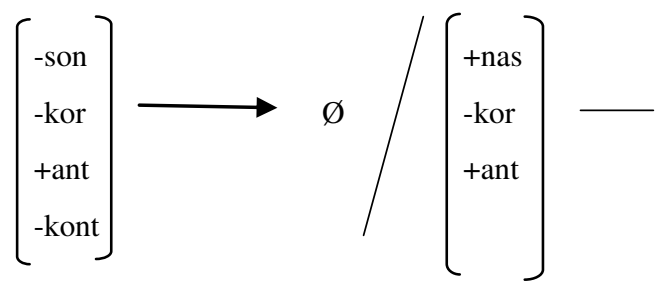

b. Formula II

The second formula is about the process of phoneme $/ \mathrm{N} /$ that is transformed into the sound [n] when it comes together with the sound [t]. Therefore, the assimilation process can be seen from the data below:

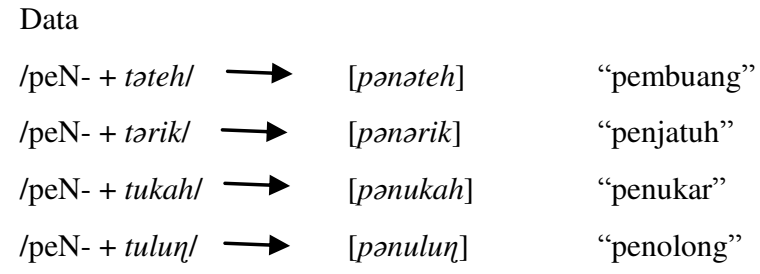

The data above indicate that uvular nasal consonant /N/ will turn into alveolar nasal $[\mathrm{n}]$ when it appears before alveolar plosive $[\mathrm{t}]$, and the occurrence of deletion of the initial phoneme in the basic feature. The sound $[\mathrm{n}]$ is resulted from the fusion $[\mathrm{t}]$ and the transformation process from $/ \mathrm{N} /$ into the sound $[\mathrm{n}]$. The assimilation process occurs in the sound which follows. Consequently, the distinguishing characteristic and its formula will be explained below:

The first assimilation process

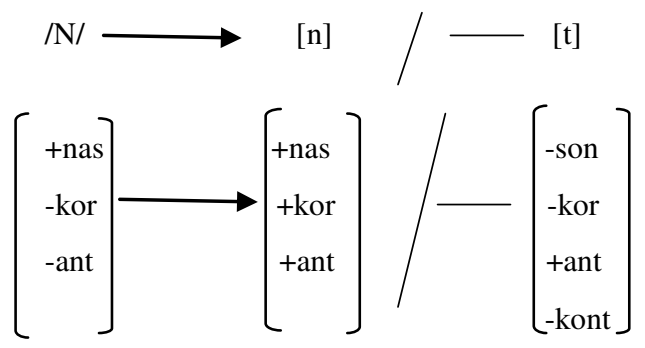


The assimilation process with the sound that follows and this formula appears as the consequence of process. Deletion is the process of deleting one of the sounds toward the word where the affixation process takes place. The second assimilation process will be presented as follows:

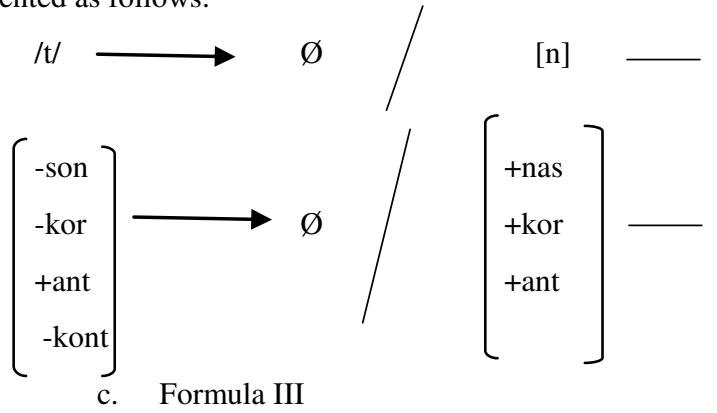

The third formula is about the process $/ \mathrm{N} /$ that is transformed into the sound [n] when that phoneme converges the sound [s]. Here is some examples of data, they are:

Data example:

\begin{tabular}{|c|c|c|}
\hline /peN- + sion/ & [pənion] & "penggoreng" \\
\hline /peN- + sәpuh/ & [рәпәриһ] & "penyapu" \\
\hline 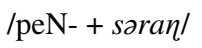 & [pәләraп] & "penyisir" \\
\hline /peN- + sadut/ & [pәләdut] & "pembakar" \\
\hline /peN- + sarik/ & [panərik] & "penghapus" \\
\hline
\end{tabular}

Based on the data examples that have been presented above, the result of analysis indicates that there are two assimilation processes occured; first, the process of phoneme transformation of uvular nasal consonant /N/ will turn into palatal nasal [n] when it appears before the phoneme [s] alveolar fricative; second, its fusion process occurs in the beginning phoneme which is phoneme [s]. Then, the distinguishing characteristic and its formula are presented in the following analysis:

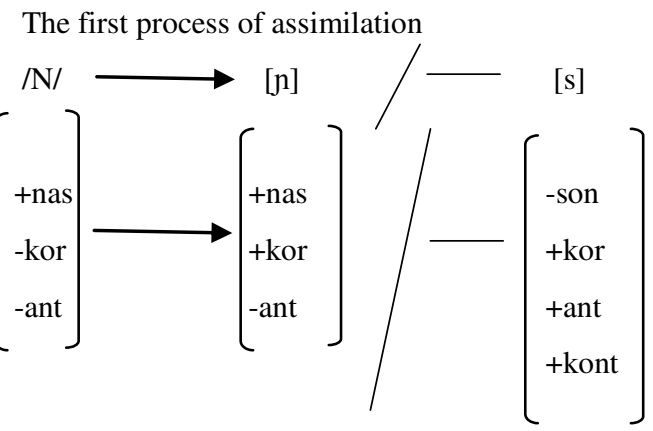

The second process of assimilation

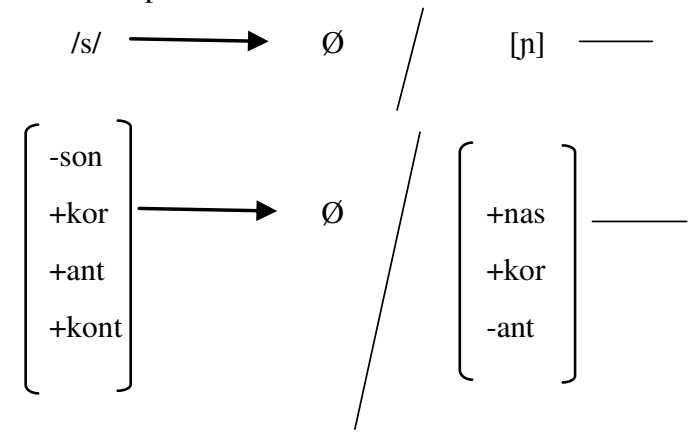

\section{d. Formula IV}

The last formula is about the process of $/ \mathrm{N} /$ which turns into [n] when that phoneme occurs together with the vowel $[\mathrm{k}, \mathrm{g}]$. It will be begun with the analysis of assimilation process of vowel-consonant; the phonological process that occurs when the vowel gets the characteristic from the adjacent consonant. Meanwhile, the data related to the formula IV are presented below:

Data 1

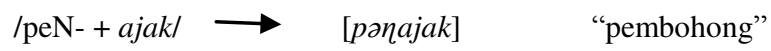

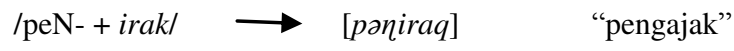

$$
\begin{aligned}
& \text { /peN-+ukiql } \longrightarrow[\text { pəqukiq }] \longrightarrow \text { "pengorek" }
\end{aligned}
$$

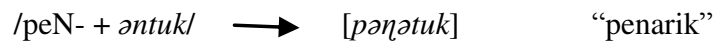

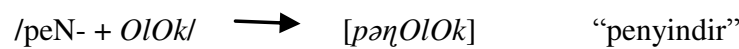

Data 1 indicate that $/ \mathrm{N} /$ alveolar nasal will turn into [ $\mathrm{\eta}$ retroflex nasal after it comes together with the vowel phoneme. This case occurs because the vowel phoneme gets a particular characteristic from the consonant. The vowel is often phonetically nasalized when it converges the nasal consonant. This assimilation process will be explained in phonological formula below:

The first assimilation process

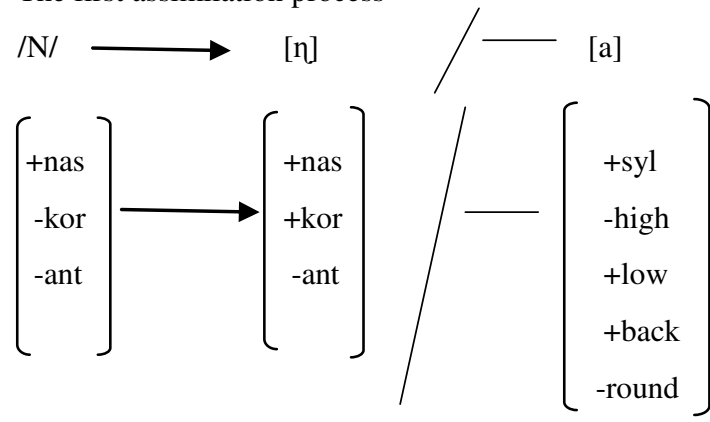

The second assimilation process
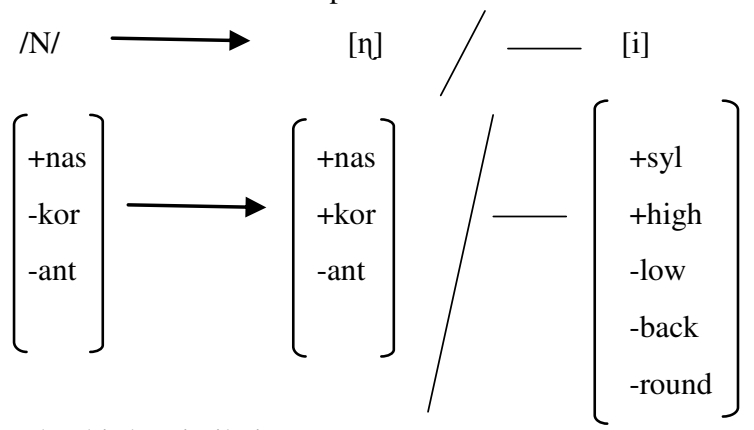

The third assimilation process
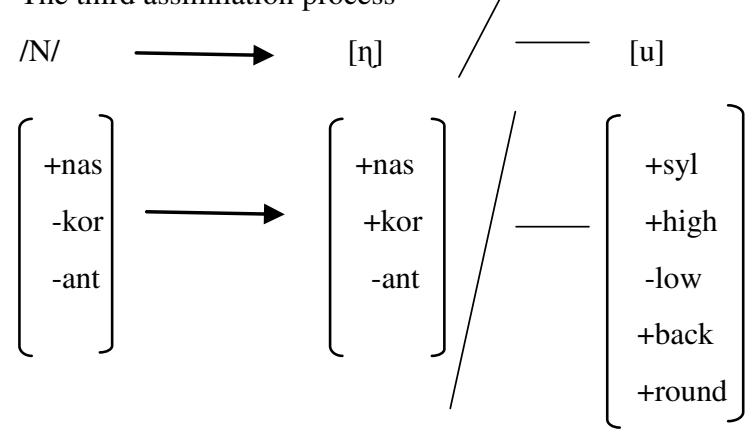
The fourth assimilation process

/N/

[n]
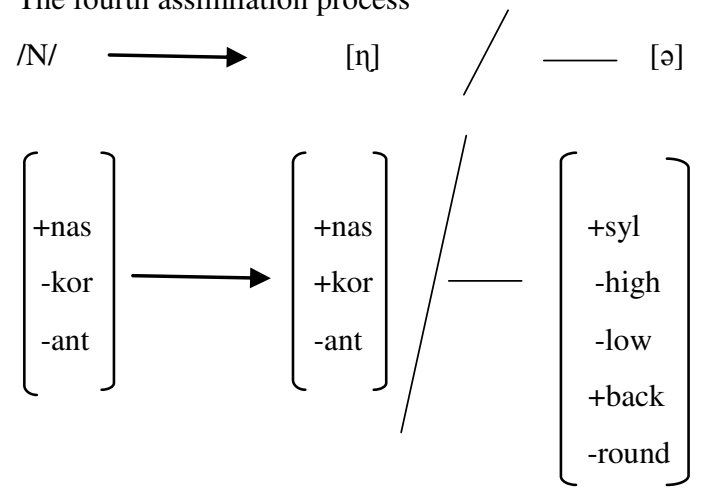

The fifth assimilation process

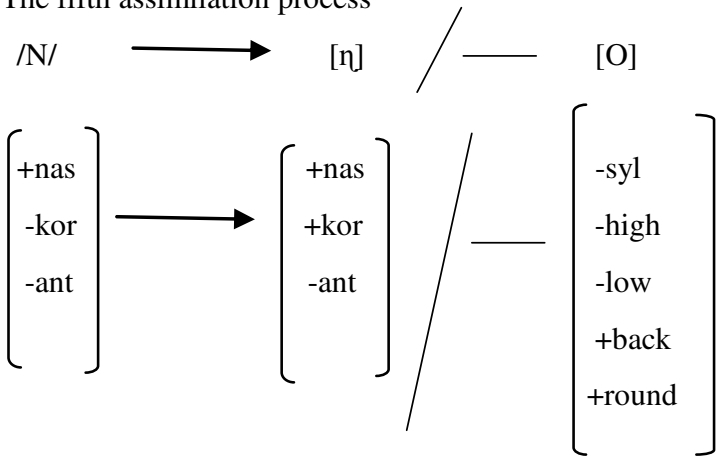

Data 2

\begin{tabular}{|c|c|c|}
\hline /peN- + kalak/ & 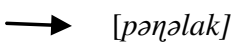 & "pemasak" \\
\hline /peN- + kraiq/ & $\rightarrow \quad[$ panraiq $]$ & "penggaruk" \\
\hline /peN- + kalik/ & 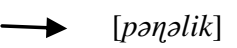 & "penggali \\
\hline /peN- + kodək/ & 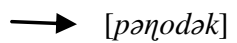 & "pengecil" \\
\hline
\end{tabular}

From data 2, it can be concluded that there are two occurrences of assimilation process; first, the transformation process toward the phoneme of uvular nasal consonant /N/ will turn into retroflex nasal [ $\mathrm{\eta}$ ] when it appears before the phoneme [k] velar plosive; second, the fusion process occurs in the initial phoneme toward the stem, which is the phoneme $[\mathrm{k}]$. The appearance of those both formulas is considered as the consequence of assimilation process. The distinguishing characteristic and the formula will be presented in the analysis as follows:

The first assimilation process

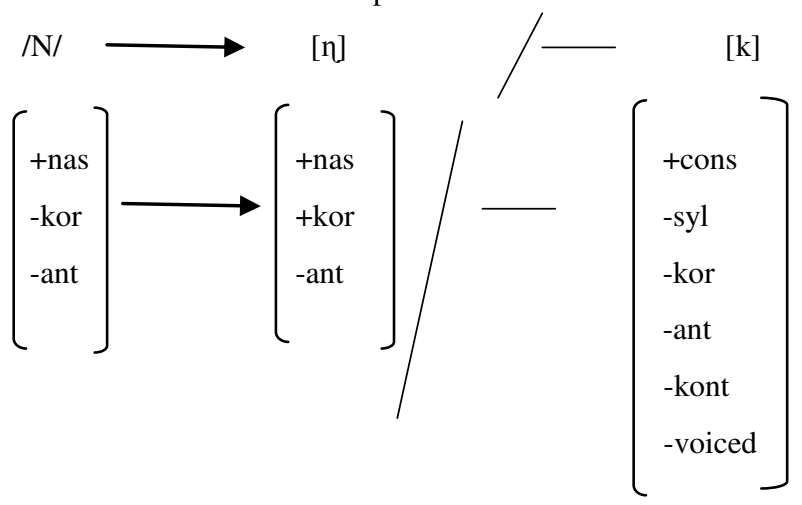

The second assimilation process

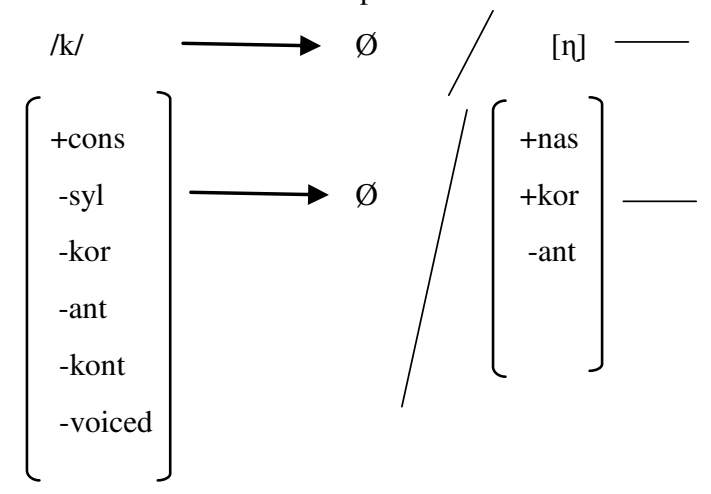

Data 3

$$
\begin{aligned}
& \text { /peN- + garol } \longrightarrow \text { [pangaro] "pengering" }
\end{aligned}
$$

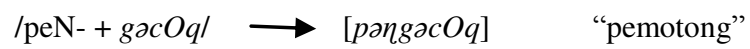

Data 3 indicate that uvular nasal consonant $/ \mathrm{N} /$ is going to turn into retroflex nasal $[\mathrm{n}]$ if it appears before $[\mathrm{g}]$ velar plosive, so the distinguishing characteristic and the formula will be as follows:

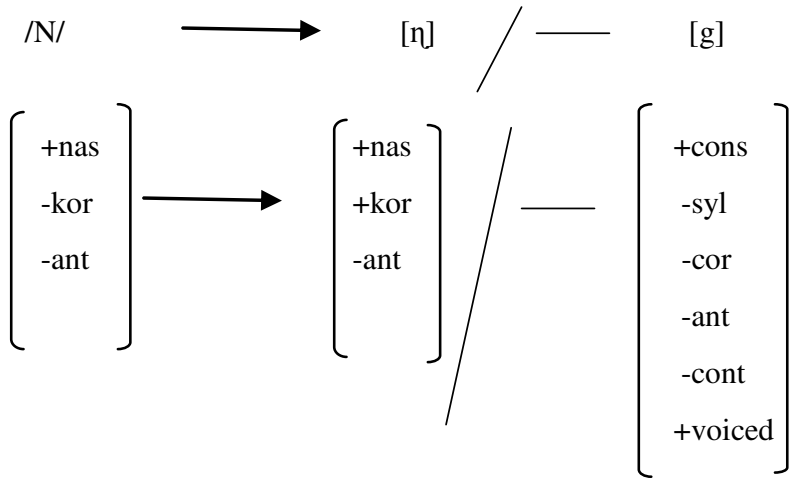

In this study, the phoneme $[\mathrm{k}]$ and $[\mathrm{g}]$ are distinguished into the formula analysis of the distinguishing function, because the phoneme [k] is -voiced, while the phoneme [g] is +voiced. Furthermore, from the data that have been analysed in the previous section, prefix paNin Sasak, phonologically, has the formula and the same meaning which is to explain the doer/actor (noun).

\section{CONCLUSION}

Based on the data analysis that has been explained above, it can be concluded that the phonological process in the prefix of Sasak has the formula and the same meaning; it is realized as the doer/ actor (noun). The assimilation process occurs from the sound nasal $\mathrm{N}$ that comes together with the consonant or the vowel, and causes the sound change toward the phoneme. 


\section{REFERENCES}

\section{BOOKS}

Basic Format For Books

Chaer, A. (1994). Linguistik Umum. Jakarta: Rineka Cipta.

Sudaryanto. (1993). Metode Dan Aneka Teknik Analisis Bahasa (Pengantar Penelitian Wahana Kebudayaan Secara Linguistis). Yogyakarta: Duta Wacana University Press.

A Translation

Gunawan, K. (1992). Fonologi Generatif. (S. A. Schane). Jakarta: PT Gelora Aksara Pratama. (Original work published 1973)

\section{OTHER PRINT SOURCES}

Article From an Online Periodical with no DOI Assigned

Yusdarani, B. I. (2015). Morfofonemik Bahasa dalam Proses Afiksasi Bahasa Sasak Desa Montong Baan Kecamatan Sikur Lombok Timur. Retrieved from http://www.academia.edu/13156536/morfofonemik bahasa _sasak_desa_montong_baan

Aisyiyah, M. N. Proses Fonologis pada Prefiks /mo-/ dalam Bahasa Gorontalo. Retrieved from http://www.academia.edu/6814166/proses_fonologis_pada _prefiks_mo-_dalam_bahasa_gorontalo

Article

Sartini, N. W. (2012). Bahasa Pergaulan Remaja: Analisis Fonologi Generatif. Surabaya: Universitas Airlangga. 